\title{
APPLICATION OF RAILWAY SAFETY SYSTEM RADIOBLOCK
}

\begin{abstract}
This paper focus on description of railway safety system radioblock and its application. Content of the paper describes usefulness of this system on those railway lines, which have been operated according to norm about simplified supervision of railway operation. Theoretical basis of the research is proved by case study on the railway line Číčenice - Volary (Czechia). This railway line is the only railway line with this safety system nowadays. Application of these issues is evaluated from safety and technology point of view. There are some suggestions for other railway lines, which are suitable for radioblock railway safety system.
\end{abstract}

Keywords: railway transport, railway infrastructure, safety system, radioblock

\author{
Martin Vojtek ${ }^{1}$ \\ ${ }^{1}$ University of Zilina, Faculty of Operation and Economics of Transport and Communications, Department \\ of Railway Transport, Univerzitna 1, 01026 Zilina, Slovakia; $+42141513 \quad 34 \quad 34$; \\ martin.vojtek@fpedas.uniza.sk \\ Jan Kugler ${ }^{2}$ \\ ${ }^{2}$ KPT rail s.r.o., Erbenova 2978, 39002 Tabor, Czechia; +420 606564 029; jan.kugler@kptrail.cz \\ Jaroslav Matuška ${ }^{3}$ \\ 3 University of Pardubice, Faculty of Transport Engineering, Department of Transport Technology \\ and Control, Studentska 95, 53210 Pardubice, Czechia;+420 466036 420; jaroslav.matuska@upce.cz \\ Martin Kendra ${ }^{4}$ \\ ${ }^{4}$ University of Zilina, Faculty of Operation and Economics of Transport and Communications, Department \\ of Railway Transport, Univerzitna 1, 01026 Zilina, Slovakia; +421 $41 \quad 513 \quad 34 \quad 29$; \\ martin.kendra@fpedas.uniza.sk
}

\section{Introduction}

Railway transport is considered as fast, safe and comfortable way of transportation. Safety of railway operation is one of the main and factor with significant impact on the quality of passenger transportation and freight transportation too. Level of safety on railways is influenced by railway safety system, what is a complex of technical equipment and administrative arrangements. The main task of railway safety system is to eliminate all failures caused by people. (Gašparík, et al., 2017)

Safety system radioblock is one of many types of safety systems, which are used on railway lines. There are described its components and functionalities on each level of the safety system. Evaluation of this safety system compared from safety and technology point of view. The comparison is focused on railway operation on selected route Číčenice - Volary according to norms of Czech railway infrastructure manager SŽDC D3 and SŽDC D4. Railway line Číčenice - Volary was operated as simplified supervision of railway operation therefore there was not any safety system. Incidence of some extraordinary events led to make the safety system on this railway line. Czech railway infrastructure manager SŽDC wants to prevent such extraordinary events in the future.

\section{Radioblock description}

Radioblock RBA-10 is the complex of technical equipment and administrative arrangements, which create the system for managing and securing the railway operation mainly on regional railway lines. This system was made for increasing the level of safety on these railway lines and to prevent all failures made by people.
This system is created with minimum investment and operating costs. It is intended for usage on one-track railway lines with maximum speed $100 \mathrm{~km} / \mathrm{h}$. Maximum number of traffic control points is 35 and maximum number of trains is 16 in one moment. In all traffic control points the maximum number of tracks is 4 . Radioblock system is based on radio communication between radioblock headquarters and vehicles. (Brejcha, 2009)

Some of the basic functions provided by technical parts in RBA-10 facilities are:

1. Rejection of conflict permissions such as train rides to opposite direction on one track,

2. Actual conditions of the whole area are displayed to dispatcher of the radioblock,

3. Electronic transport documentation and data could be transferred,

4. Conditions of downloaded permissions are displayed to vehicle-drivers,

5. Rejection of train ride without permission and control of vehicle-drivers' acts connected to location of the train according to permission by using GPS with warning signals,

6. Control of basic condition on infrastructure in railway stations,

7. Possibility of emergency STOP signal,

8. Possibility for operation of railway vehicles without radioblock facility by substitute acts of dispatcher.

Radioblock headquarters is a complex of technical equipment situated in the dispatching centre. Its purpose is to control train rides in the selected area. It enables sending data and voice permissions for vehicle-drivers. Radioblock vehicle facility is a complex of technical equipment which display permissions from dispatcher directly to vehicle- 
driver. Train location is also available there. Basic parts are actuating device connected to display.

Basic level of radioblock railway safety system is signed as RB 0. Added Satellite navigation creates level RB 0+. Another level RB 1 uses GNSS. Radioblock level RB 2 means that there is exact control of permissions by measuring the ridden distance. This level of radioblock is not practically used. Radioblock facility in the vehicle has these functions:

1. Automatic check-out,

2. Control of permissions and its compliance with possibility of emergency break activation,

3. Maximum speed limit,

4. Actual speed with possibility of emergency break activation,

5. Integrity of the train,

6. Simple train login,

7. Conditions of crossing safety systems,

8. Information about contemporary speed restrictions.

In the conditions of railway transport, it is not possible to ensure continuous GNSS signal because there are tunnels, deep forests etc. For this reason, on the radioblock facility in the vehicle, there can be switched the level of its functionality. Current level must be shown to vehicle-driver on the display.

Table 1. Threats and their prevention according to the radioblock level of functionality

\begin{tabular}{|c|c|c|c|c|}
\hline THREAT & RB 0 & RB 0+ & RB 1 & RB 2 \\
\hline $\begin{array}{c}\text { Incorrect } \\
\text { permission }\end{array}$ & YES & YES & YES & YES \\
\hline $\begin{array}{c}\text { Departure } \\
\text { without } \\
\text { permission }\end{array}$ & YES & YES & YES & YES \\
\hline $\begin{array}{c}\text { Incorrect } \\
\text { train location }\end{array}$ & NO & WARNING & YES & YES \\
\hline
\end{tabular}

Organising of railway transport operation on the railway line, where Radioblock railway safety system is implemented, is provided by permission to train ride. This permission is issued by dispatcher and then it is delivered to the vehicle facility by radio data network. This permission is displayed by vehicle facility therefore it is necessary to have this facility on each vehicle, which are riding on that railway line. (Brejcha, 2009)

Spatial sections on the railway line with radioblock railway safety system is divided by station borders. In front of each station on railway line with radioblock railway safety system, there must be entrance signal with its foreboding. On these signals, there must be number of that railway track in the station, where train is going to arrive in basic conditions. Symbol X is used in that case, when the station is managed from radioblock dispatching centre. Every train on the railway line with radioblock railway safety system, must be recorded and logged into radioblock dispatching centre. Login can be done electronically or vocally. From the beginning of the login until the logout, the status of the vehicle is recorded, and this status is known as mode.
Table 2. Modes and data permissions overview

\begin{tabular}{|c|c|}
\hline Mode & Explanation \\
\hline No permission & $\begin{array}{c}\text { Departure of the vehicle will stop the } \\
\text { vehicle }\end{array}$ \\
\hline $\begin{array}{c}\text { Permission to } \\
\text { ride }\end{array}$ & $\begin{array}{c}\text { Train can ride on selected railway } \\
\text { section }\end{array}$ \\
\hline $\begin{array}{c}\text { Vehicle-driver } \\
\text { responsibility }\end{array}$ & \begin{tabular}{c} 
Ride according to vocal permissions \\
\hline Shunting
\end{tabular} \\
\hline
\end{tabular}

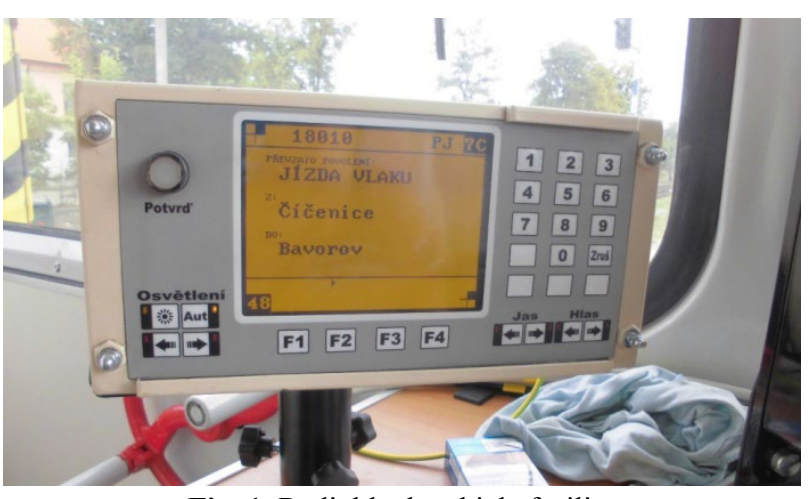

Fig. 1. Radioblock vehicle facility

\section{Railway line Č́ícenice - Volary}

Railway line is signed by number 197 in SŽDC timetable. The beginning of this railway line is in the railway station Číčenice. There is another electrified railway line number 190 České Budějovice - Plzeň, where long-haul trains are also operated. In railway station Volary, there is other railway line number 198 Strakonice - Volary. In railway station Černý Kříž, there is other railway line number 194 České Budějovice - Černý Kříž. The entire end of this railway line is in the station Nové Údolí. Overall distance of the railway line is $70 \mathrm{~km}$. In the section Č́íčenice - Volary, railway transport is operated according to norm SŽDC D4. In railway stations Číčenice and Volary, there are dispatchers therefore these railway stations are autonomous. These dispatchers organise primarily railway transport in those railway stations. Dispatching centre for radioblock railway safety system on this railway line is in the station Prachatice, which is also autonomous station. It means that dispatcher of radioblock centre is also a dispatcher for this railway station. (Schreier, 2004)

\section{Railway safety system purpose}

Safety is the dominant criterion of transportation. It is generally guaranteed by norms, licences, permissions, certificates and verifications. Transportation safety is measured by indicator of accidents per one billion passenger-kilometres - number of passengers transported per one kilometre. According this way statistics, railway transport is one of the safest modes of transportation. (Kampf, et al., 2012) 
Main goal of the radioblock railway safety system is to increase the level of safety in railway operation on regional railway lines. In conditions of Czechia, it is determined for railway lines, where railway operation is done according to norm SŽDC D3. On railway lines with simplified supervision of railway operation, the whole responsibility is on operational staff. There is not any railway safety system therefore the railway transport operation is done by supervising of competent person. Telephonic communication between dispatcher and vehicle-driver is recorded. Every mistake such as departure from station without permission could have fatal consequences. (Zitrický, et al., 2015)

There were some extraordinary events on the railway line Číčenice - Volary when this railway line was operated according to norm SŽDC D3 until year 2011. This was the main reason to build radioblock railway safety system on this regional railway line. Most of accidents was caused due to mistake of people therefore railway safety system could prevent these accidents. Reasons of these accidents were departures from station without permission or mistakes in communication.

Table 3. Extraordinary events on this railway line

\begin{tabular}{|c|c|c|c|}
\hline Year & Event & Death / Injury & Costs (€) \\
\hline 2004 & major accident & $2 / 33$ & 160000 \\
\hline 2007 & major accident & $0 / 13$ & 5500 \\
\hline 2011 & major accident & $1 / 15$ & 280000 \\
\hline 2013 & accident & $0 / 0$ & 10000 \\
\hline
\end{tabular}

\section{Technology of railway operation}

On each railway line with simplified supervision of railway operation, there is on railway station, from where the dispatcher organises the whole railway line. This dispatcher provides permissions for ride to every train, which is on the railway line. All trains on that railway lines have recording obligation in selected traffic control points. These traffic control points are stated in special timetable for vehicle-drivers. In case of shunting, dispatcher must set exact time for shunting. After the end of shunting, vehicledriver must report that tracks are free. Railway line with radioblock railway safety system (norm SŽDC D4) is supervised by dispatcher, who provides all permissions for each train in selected area. Contrast to railway lines with simplified supervision of railway operation, there is a safety system, which eliminates mistakes of people. (Černá, at al., 2016)

Besides increased safety of railway operation, radioblock railway safety system has also other positive impacts to quality of passenger transportation. Duration of operational intervals in every station were decreased therefore traveling time was also decreased. In every traffic control points, there were built new platforms for each direction. New platforms have level crossings with tracks. These platforms are $250 \mathrm{~mm}$ above the track according to norm 398/2009 General technical requirements for people with reduced mobility, better known as TSI PRM. There was also build new lighting system in each traffic control point with photocell and video recording system. Information about arrivals, departures, delays and extraordinary events are provided for passengers by special radio system. This system is controlled by radioblock dispatcher in railway station Prachatice. There were not so great decreases in traveling time due to connected trains on other railway lines. Traveling time can be decrease by radioblock railway safety system on this railway line only in case of:

1. Increase the speed limit from $60 \mathrm{~km} / \mathrm{h}$ to $100 \mathrm{~km} / \mathrm{h}$,

2. Decrease static parts of operational intervals in railway stations.

\section{Radioblock on other railway lines}

On the SŽDC railway network, there are 82 railway lines, which are operated according to norm SŽDC D3. Some of these railway lines do not need radioblock railway safety system because operation on those railway lines is not so high. There is only one traffic control point or there is only one vehicle on the whole railway line. Some of these railway lines are without any regular traffic. On the other hand, there are many railway lines, which are not so suitable for norm SŽDC D3 because of rush traffic or many control points.

Table 4. Railway lines suitable for radioblock

\begin{tabular}{|l|l|l|}
\hline Railway line & Km & Ctrl points \\
\hline Vimperk - Volary & 37 & 3 \\
\hline Strakonice - Vimperk & 32 & 4 \\
\hline Chornice - Třebovice v Č. & 36 & 3 \\
\hline Kostelec n. H. - Chornice & 34 & 3 \\
\hline Kostelec n. H. - Senice n. H. & 19 & 2 \\
\hline Teplice n. M. - Trutnov střed & 32 & 4 \\
\hline $\begin{array}{l}\text { Blatno u J. - Bečov n. T. + } \\
\text { Protivec - Bochov }\end{array}$ & 76 & 8 \\
\hline $\begin{array}{l}\text { Mar. Lázně - Karlovy Vary } \\
\text { d.n. + Kr. Jez - H. Slavkov- } \\
\text { Kounice }\end{array}$ & 59 & 9 \\
\hline Nejdek - Potı̊čky & 27 & 4 \\
\hline Mělník - Mladá Boleslav hl.n. & 49 & 4 \\
\hline Suchdol n. O. - Budišov n. B. & 39 & 5 \\
\hline Bělá n. R. - Tachov & 40 & 3 \\
\hline Domažlice - Bělá n. R. & 37 & 2 \\
\hline $\begin{array}{l}\text { Jindřich. Hradec - Nová } \\
\text { Bystřice }\end{array}$ & 30 & 9 \\
\hline Jindčichův Hradec - Obrataň & 44 & 9 \\
\hline Choceň - Litomyšl & 24 & 4 \\
\hline Vsetín - Velké Karlovice & 27 & 3 \\
\hline Rybník - Lipno and Vltavou & 22 & 4 \\
\hline Cáslav m. n. - Třemošnice & 17 & 4 \\
\hline Tanvald - Harrachov st. hr. & 13 & 4 \\
\hline Pňovany - Bezdružice & 24 & 4 \\
\hline Jilemnice - Rokytnice n J. & 16 & 4 \\
\hline
\end{tabular}


Evaluation of railway lines in Czechia, which are suitable for radioblock railway safety system, was done according to determined criteria:

- Number of traffic control points on the railway line,

- Length of the railway line $(\mathrm{km})$,

- Current regular traffic,

- Train crossings in traffic control points.

Proposed railway lines are suitable for radioblock railway safety system. Radioblock can increase the safety of railway transport operation and throughput of the railway line. It is also possible to decrease traveling time. It is necessary to have radioblock vehicle facility on each vehicle, what increase costs for transport companies. Disadvantage of using radioblock is still opened problem of connection between regional railway lines and main railway lines, where is European traffic control system ETCS. (Šrámek, et al., 2018)

\section{Conclusions}

1. Railway safety system radioblock is built for those regional railway lines, where simplified supervision of railway operation according to norm SŽDC D3 is used now.

2. Radioblock railway safety system is provided on various levels. The highest level is connected to satellite systems GNSS for identification of exact train location. Using of GNSS is cheaper than using of location equipment on the track.

3. There is possibility to increase maximum speed on the railway line to $100 \mathrm{kph}$. Traveling time can be decreased and some technological tasks in railway stations are not necessary.

4. There is only one railway line with radioblock railway safety system. It is railway line Číčenice - Volary in Czechia. Occurrence of extraordinary events on this railway line led to building of this safety system. Another railway line Dolní Bousov - Kopidlno is ready for building updated version of radioblock railway safety system.

5. In Czechia, there are many railway lines suitable for radioblock railway safety system. These railway lines were proposed according to selected criteria. They are not suitable for simplified supervision of railway operation because of high number of stations or rush traffic on them.

\section{Acknowledgement}

The paper was supported by the VEGA Agency, Grant No. 1/0509/19 "Optimizing the use of railway infrastructure with support of modal split forecasting", at Faculty of Operations and Economics of Transport and Communication, University of Žilina, Slovakia.

\section{References}

Brejcha, R. 2009 Výpočet provozních intervalů na tratích řízených podle predpisu SŽDC D3. /Calculation of operational intervals on railway lines which are operated according to norm SŽDC D3/. In: Vědeckotechnický sborník ČD [online]. Prague: Generální ředitelství Českých drah, ISSN 1214-9047.

Černá, L., Dolinayová, A., Daniš, J. 2016 Identification of Risks in Railway Transport and the Proposal for Their Price Evaluate, In: Proceedings of 20th International Scientific Conference. Transport Means (5-7 October 2016, Juodkrante, Lithuania), Kaunas, Lithunania, pp. 414-419

Dolinayová, A., Daniš, J., Černá, L., 2017 Regional Railways Transport - Effectiveness of the Regional Railway Line, Conference on Sustainable Rail Transport (RailNewcastle), Newcastle Univ, Newcastle upon Tyne, England, Lecture Notes in Mobility, p. 181-200

Gašparík, J., et al. 2017 Railway Traffic Operation, 292 p., ISBN: 978-80-554-1281-8.

Gašparík, J., et al. 2014 Methodology for assessing the quality of rail connections on the network, Komunikacie, 16, pp. 2530

Gašparík J., Stopka O., Pečený L. 2015 Quality evaluation in regional passenger rail transport, Naše more, vol. 62, no. 3, pp.114-118

Gašparík, J., Abramovič, B., Zitrický, V., 2018 Research on dependences of railway infrastructure capacity. In: Technički Vjesnik /Technical Gazette/. ISSN 1330-3651 25(4): p. $1190-1195$.

Kampf R., Ližbetin J., Ližbetinová L. 2012 Requirements of a transport system user, Communications, vol. 14, no. 4, pp. 106-108

Prohlášení o dráze celostátní a regionální. /Network statement/. 2019. Prague: SŽDC, 2018.

Schreier, P. 2004 Zrození železnic v Čechách, na Moravě a ve Slezsku. /Born of railways in Czechia, Moravia and Silesia/. Prague: Miloš Uhlír - Baset, 293 p., ISBN 807340-034-0.

Široký, J. 2014 Transport Technology and Control, p. 238. Tribun EU. Brno, ISBN: 978-80-263-0711-2.

Široký, J. 2018 Technologie dopravy: Priority dopravní politiky. /Transport technology: Transport policy priorities/. Pardubice: Institut Jana Pernera, 281 p., ISBN 978-80-7560-159-9.

Široký, J., Salaková, H. 2018 Analysis of the system of pricing of railway capacity allocation in the Czech Republic. In MATEC Web of Conferences. Vol. 235. Les Ulis: EDP Sciences, p. 1-12

Široký, J. 2017 Price for the Allocation of Railway Infrastructure Capacity as a Tool for the Improvement of Train Transport Planning. In MATEC Web of Conferences. Vol. 134.: 18th International Scientific Conference - LOGI 2017. Les Ulis: EDP Sciences,.p. 1-7

Šrámek, P. Široký, J., Hlavsová, P. 2018 Capacity range definition and calculation. In MATEC Web of Conferences. Vol. 235. Les Ulis: EDP Sciences, p. 1-6

SŽDC D3 - Předpis pro zjednodušené řízení drážní dopravy. /Norm for simplified supervision of railway operation/. 2013. Prague: SŽDC, 2013.

SŽDC D4 - Předpis pro řízení drážní dopravy na tratích vybavených radioblokem. /Norm for railway transport operation on railway lines with radioblock/. 2014. Prague: SŽDC, 2014.

Zitrický V., Gašparík J., Pečený L. 2015 The methodology of rating quality standards in the regional passenger transport, Transport Problems, international scientific journal, vol. 1, pp. 59-72 